\title{
A SILICA/FLY ASH-BASED TECHNOLOGY FOR CONTROLLING PYRITE OXIDATION
}

\author{
Semi-annual Technical Report
}

Reporting Period: 03/01/1998 through 08/31/1998

Author: Dr. V.P. Evangelou

Report Issue Date: 02/10/1998

DE-FG22-95PC95226--06

University of Kentucky Research Foundation

Office of Sponsored Programs

201 Kinkead Hall

Lexington, KY 40506-0057 


\section{OBJECTIVES}

\section{Overall Objective}

To investigate the potential of fly ash to control acid mine drainage (AMD) production.

\section{Broad Objectives}

a. To evaluate the role of silica contained in fly ash to control acid mine drainage production.

b. To evaluate the role of silica contained in fly ash to inhibit pyrite oxidation.

\section{SUMMARY OF TECHNICAL PROGRESS}

\section{Introduction}

The results of pyrite oxidation in mining areas are very low $\mathrm{pH}$ and elevated concentrations of iron and sulfate in the groundwater. Pyrite oxidation is therefore the main cause for acid mine drainage production. One approach to prevent AMD production is microencapsulation of pyrite crystals with an iron-oxide/silica coating (Zhang and Evangelou, 1998). Coating prevents diffusion of oxygen and $\mathrm{Fe}^{3+}$ to the crystal's surface and they are no longer able to oxidize it. The objective of this portion of the study was to test the hypothesis that fly ash is able to provide the necessary silica for iron-oxide/silica coating formation on the pyrite surfaces thus, decreasing pyrite oxidation and diminishing acid mine drainage production.

\section{Pyrite leaching column experiments by selected fly ashes}

All experiments were designed as indoor column leaching studies. The columns were approximately $5 \mathrm{~cm}$ ( 2 inches) in diameter and of $20 \mathrm{~cm}$ ( 8 inches) in height and they were loaded with a mixture of about $90 \%$ quartz sand and $10 \%$ pyrite. The ratio sandpyrite / fly ash was 7:3. Three fly ash samples were chosen for the pyrite leaching columns, with and without oxidant (Ca-hypochlorite), for silica-coating formation (Zhang and Evangelou, 1998):

- BP: High alkalinity (17.8 meq/100 g) with

$140 \mathrm{mg} / \mathrm{kg}$ soluble $\mathrm{Si}$ at $\mathrm{pH} 7$.

Surface: Fe: $0.53 \%, \mathrm{Al}: 7.58 \%, \mathrm{Fe} / \mathrm{Al}: 0.07$.

- GH2: Low alkalinity (3.5 meq/100 g) with

$200 \mathrm{mg} / \mathrm{kg}$ soluble $\mathrm{Si}$ at $\mathrm{pH} 7$.

Surface: Fe: $0.27 \%, \mathrm{Al}: 4.43 \%$, Fe/Al: 0.06 .

- GH-1S: Low alkalinity $(0.3 \mathrm{meq} / 100 \mathrm{~g})$

$60 \mathrm{mg} / \mathrm{kg}$ soluble $\mathrm{Si}$ at $\mathrm{pH} 7$.

Surface: Fe: $0.25 \%$, Al: $8.20 \%$, Fe/Al: 0.11 .

It is expected, that samples $\mathrm{BP}$ and $\mathrm{GH} 2$ will be able to establish an ironoxide/silica coating on the pyrite surface because of the high content of soluble silica. GH-lS should not be able to establish a coating because of the very low silica content. Alkalinity of all fly ash samples is not high enough to establish alkaline conditions in the columns and therefore lime was added to all columns. As oxidizer calcium-hypochlorite was used which was expected to oxidize $\mathrm{Fe}^{2+}$ and provide an iron-oxide base on the pyrite surface for condensation of silica (Zhang and Evangelou, 1996; Zhang and Evangelou, 1998; Vandiviere and Evangelou, 1998). 


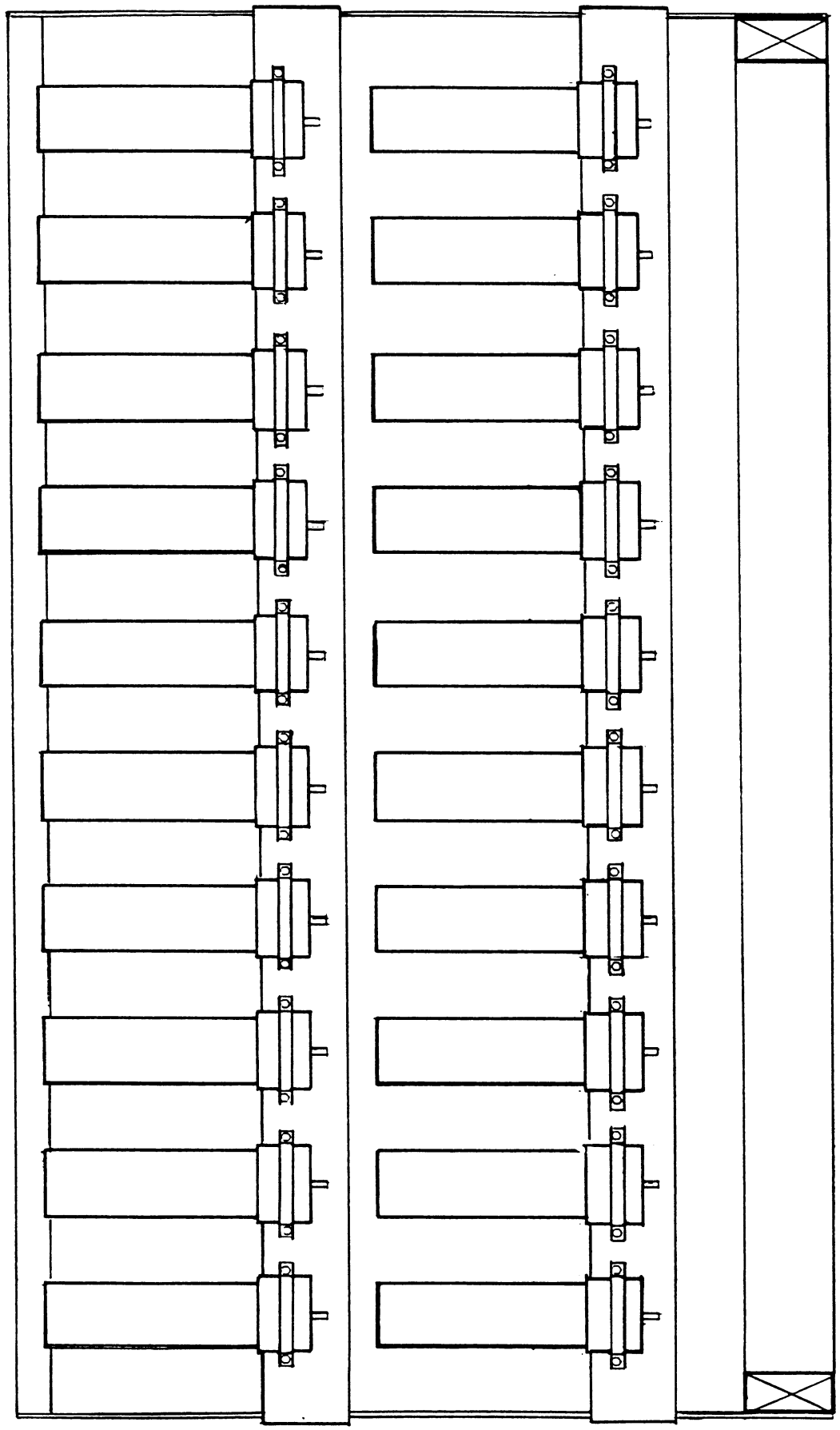

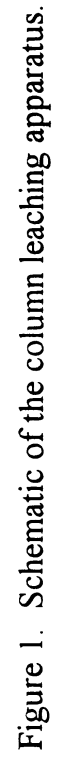


Triplicates of three fly ashes for four treatments were loaded into columns: 1) Fly ash, sand, and pyrite; 2) fly ash, sand, pyrite, and lime; 3) fly ash, sand, and lime; 4) fly ash, sand, pyrite, lime, and hypochlorite. As a control, three additional columns were loaded with sand and pyrite only. A schematic of the pyrite leaching apparatus is shown in Fig. 1.

Treatments 1, 2, and 4 contained a combination of $30 \%$ fly ash, and $70 \%$ of a $10 \%$ pyrite/ $90 \%$ clean angular sand mixture. The pulverized pyrite used in these columns was only $80 \%$ pure. In order to obtain $10 \%$ total pyrite needed for the experiment, the quantity of pyrite mixture was increased proportionally. The amount of needed lime in treatments 2,3 , and 4 was calculated by the acidity produced by the oxidation of $20 \%$ of the pyrite. The addition of lime to the columns was necessary to establish precise alkaline conditions. In treatment 4 , amounts of hypochlorite were based on the oxidation of $10 \%$ of the total pyrite in the mixture. Hypochlorite oxidized the pyrite and $\mathrm{Fe}^{+2}$ to supply an iron-oxide coating on the surface of the sample. This allowed the reaction with silica to take place. The overall calculations for the total weight of the mixture was based upon the density of the fly ashes.

The columns used were approximately $5 \mathrm{~cm}$ in diameter and $25 \mathrm{~cm}$ in height with a removable lower bed support. To prevent any clogging during oxidation due to precipitates, $105 \mathrm{~g}$ (approximately $4 \mathrm{~cm}$ ) of clean angular sand was placed in the bottom of the column., To stop the loss of material out of the column, a $149 \mathrm{~mm}$ monofilament cloth-nylon mesh was placed at the base of the lower bed support (Small Parts, Inc., Miami Lakes, FL). Depending on treatment, $125 \mathrm{~g}$ fly ash, $261.9 \mathrm{~g}$ sand, $32.3 \mathrm{~g}$ pulverized pyrite (29.1 g total pyrite available), $20.46 \mathrm{~g}$ lime, and $13.81 \mathrm{~g}$ Ca-hypochlorite were placed in a bag, and mixed thoroughly in order to distribute each component evenly. Finally, $75 \mathrm{~g}$ more of clean sand was placed on top of the mixture contained in each column. The oxidative conditions were established by constantly flushing the column with humidified air. Periodically, sampling of two pore volumes are taken by pumping deionized water through the bottom of each of the columns.

All columns were saturated with deionized water $\left(\mathrm{di}^{-} \mathrm{H}_{2} \mathrm{O}\right)$ on June 24, 1998. Leachates were collected for the first time on July 23, 1998. The columns were left dry until August thirteenth, 1998 when they were again saturated with di- $\mathrm{H}_{2} \mathrm{O}$. After one month of saturation, the second leachate sampling was collected as follows. All columns were drained, filled to saturation, drained again after four hours and both collections combined.

\section{Leachate data from the GH2 fly ash column set}

Data on chemical composition and leachate volume are presented in figures 2 - 7 . All treatments have maintained a circumneutral $\mathrm{pH}$ to date (Fig. 3). The control has dropped to $\mathrm{pH} 3.9$ and this drop is due to pyrite oxidation. The electrical conductivity (EC) of the fly ash + pyrite + lime + hypochlorite treatment was very high $(53.2 \mathrm{mmhos}$ $\mathrm{cm}^{-1}$ ) at the first sampling, but by the second sampling had dropped significantly (Fig. 3). This was due to the flushing out of the calcium $(\mathrm{Ca})$ coming from the calcium hypochlorite in these columns (see Fig. 5). There was little or no iron (Fe) concentration in the leachates collected from the treatments while the control had an increase in the amount of Fe released between the two samplings of 49 parts per million (ppm) (Fig. 6). Sulfate $\left(\mathrm{SO}_{4}-\mathrm{S}\right)$, however, was released at approximately the same rate from all columns (Fig. 7). The fly ash + pyrite + limestone + hypochlorite treatment has released the least amount of $\mathrm{SO}_{4}-\mathrm{S}$ to date.

\section{Leachate data from the GH1-S fly ash column set}

Data on chemical composition and leachate volume are presented in figures $8-13$. The $\mathrm{pH}$ of the leachates collected from the control and the fly ash + pyrite columns 


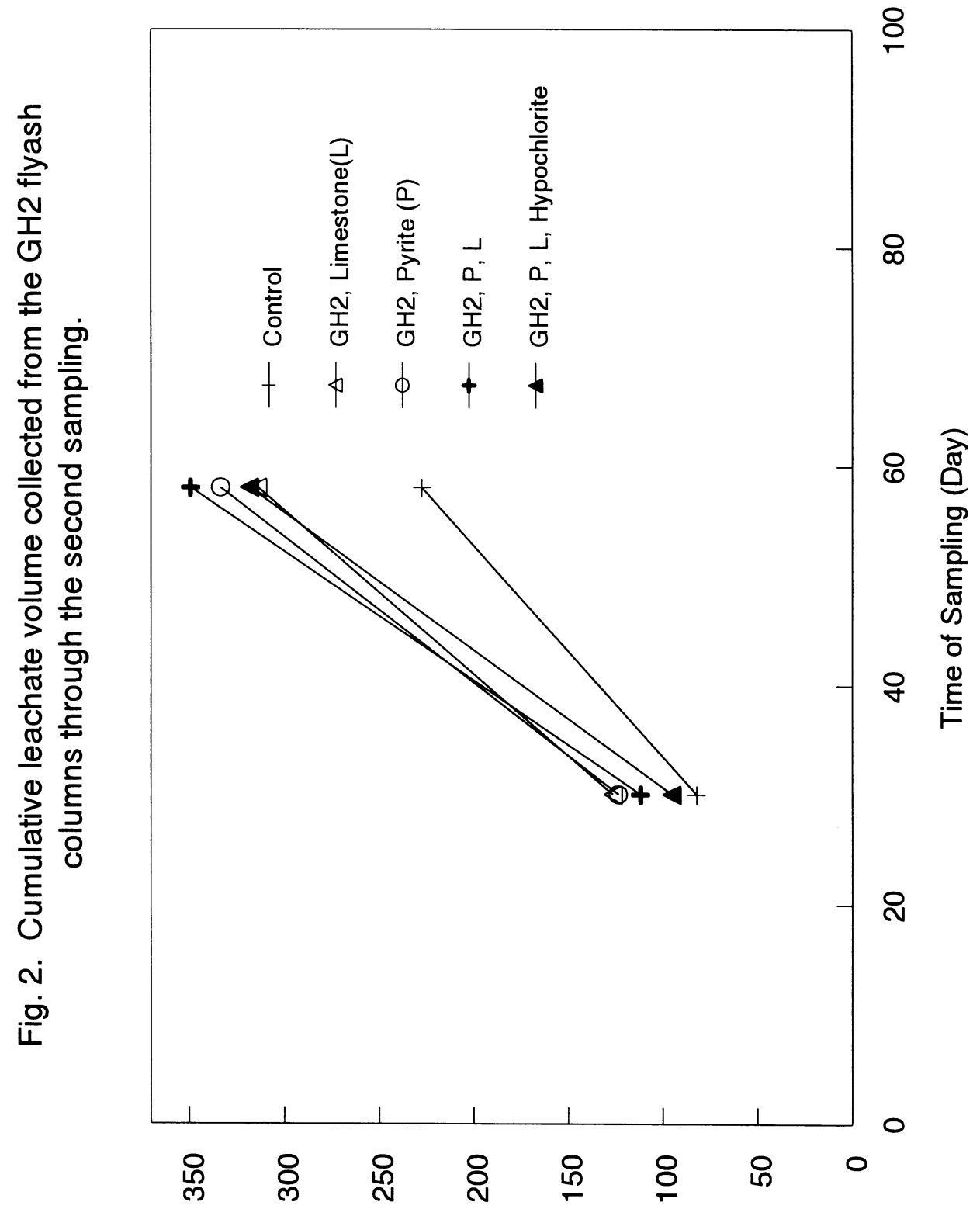

(ן) әun|ол әјечәеәך 


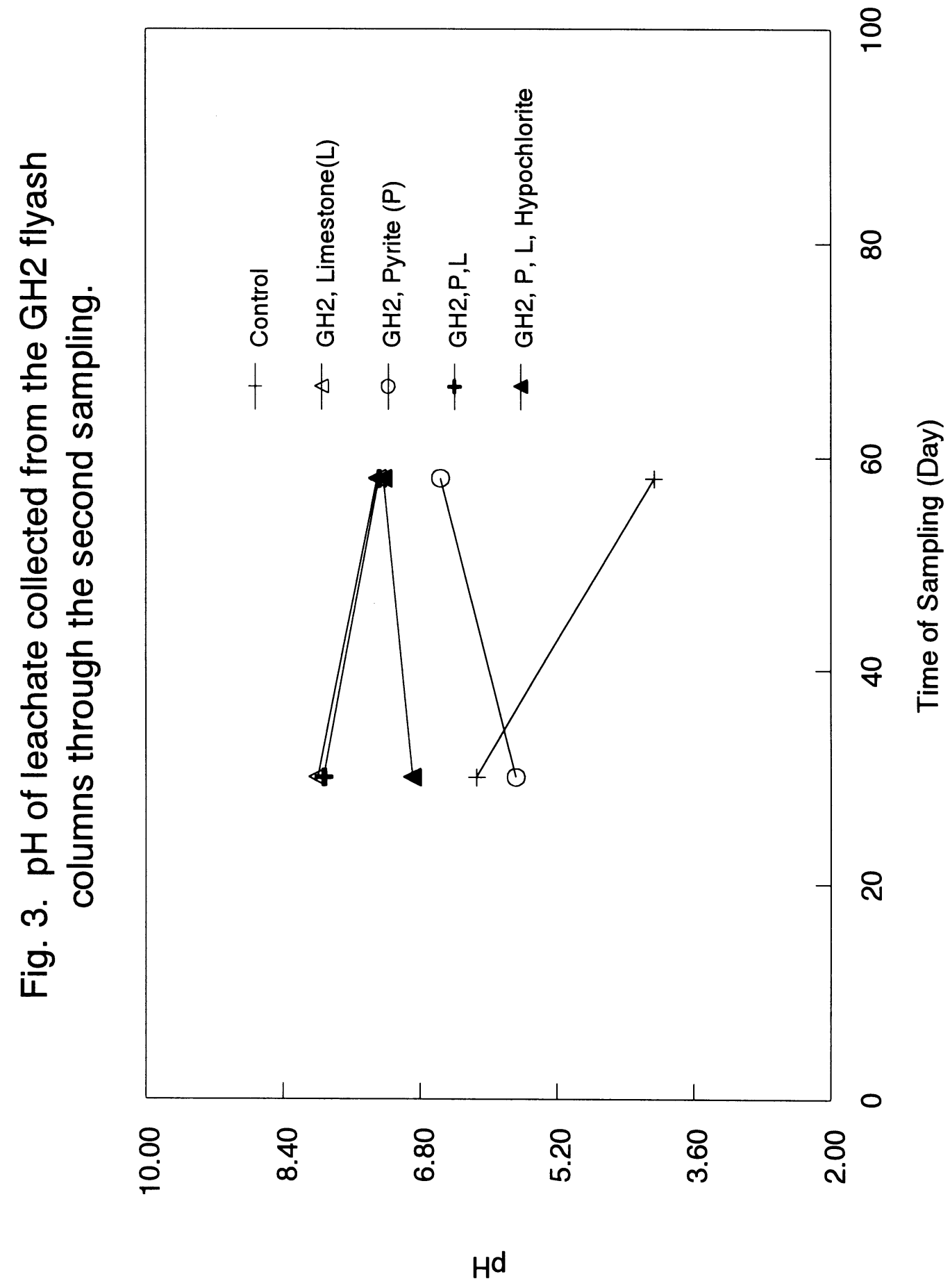




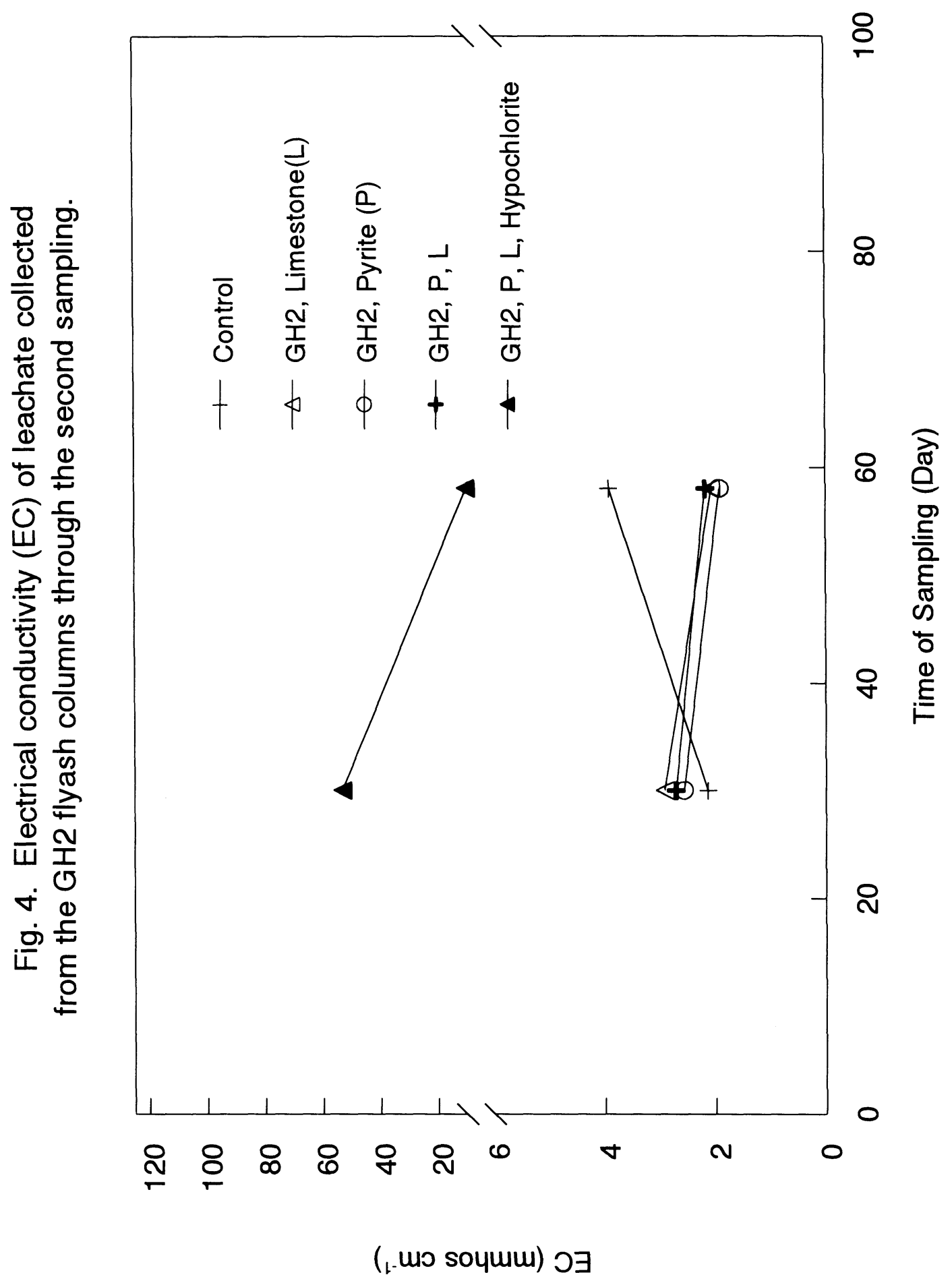




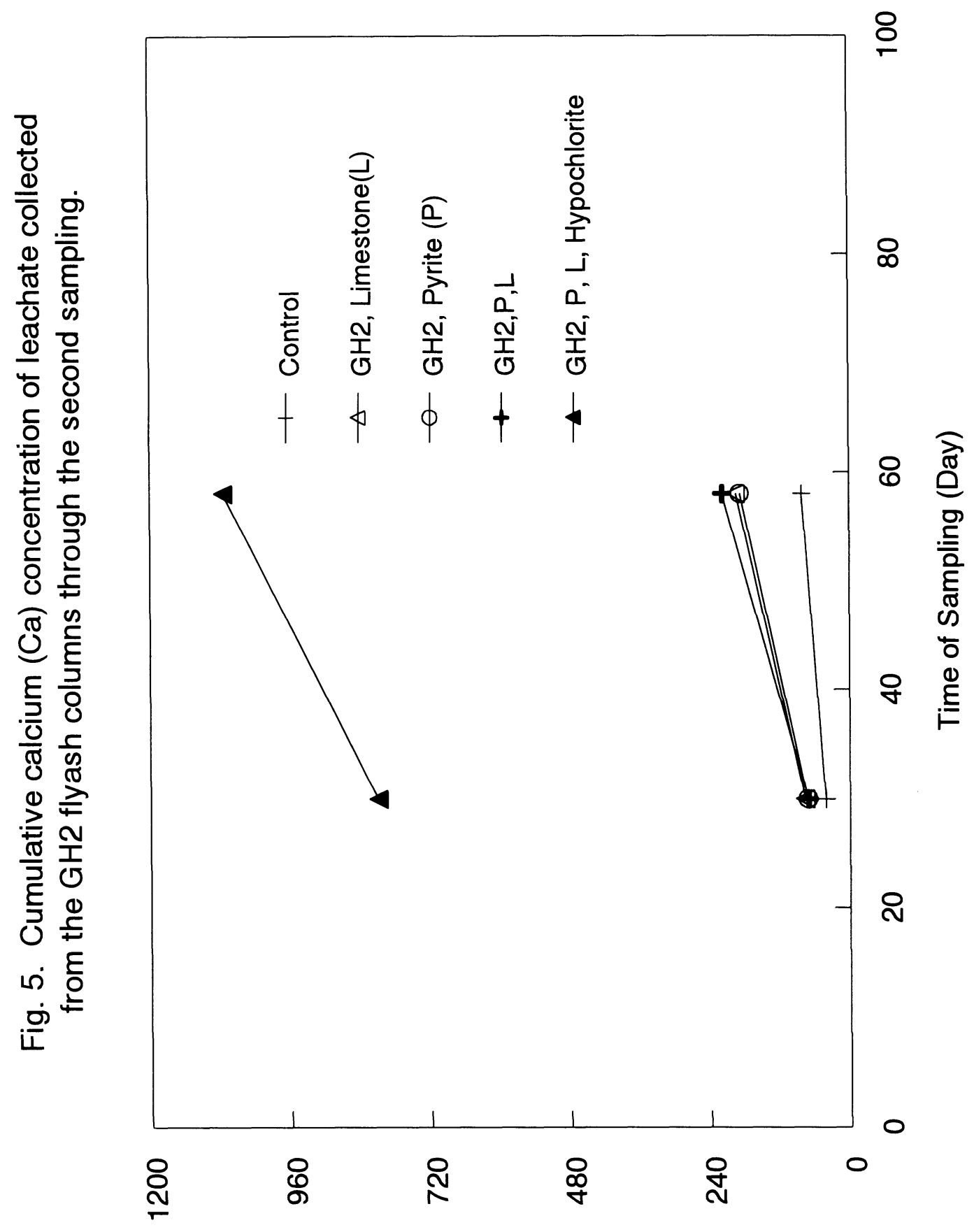

(..7 6m) uo!̣enquəsuos eว 


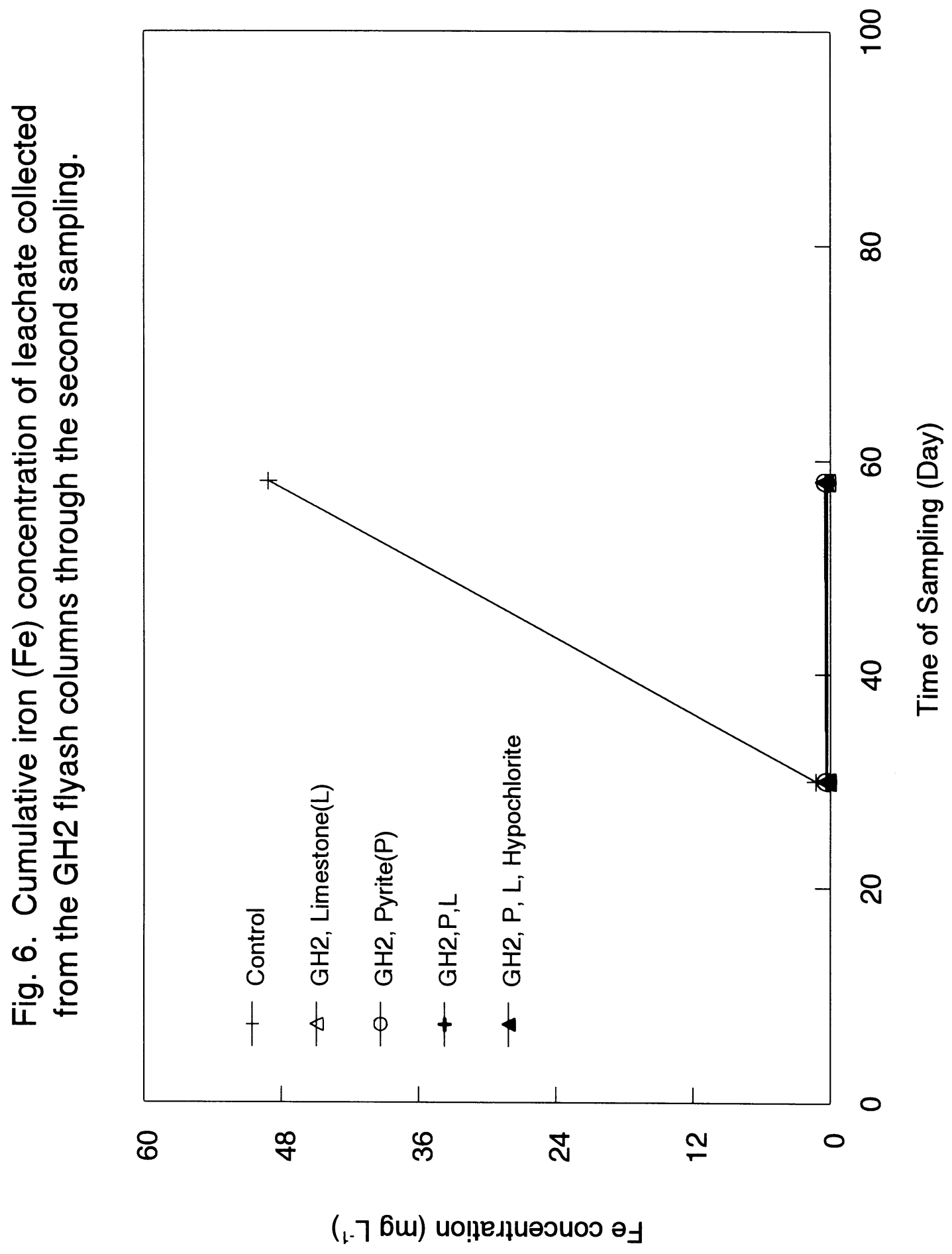




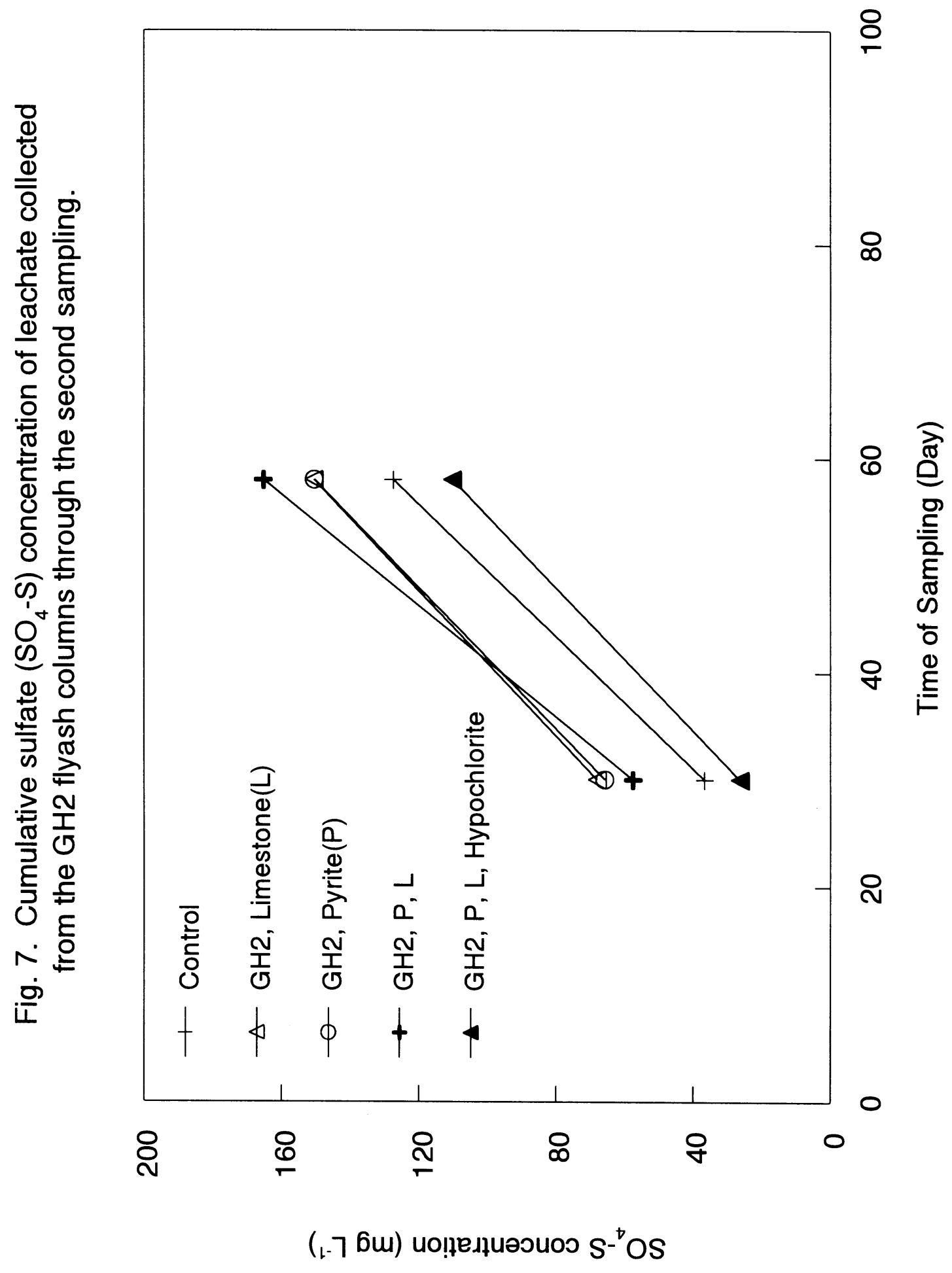




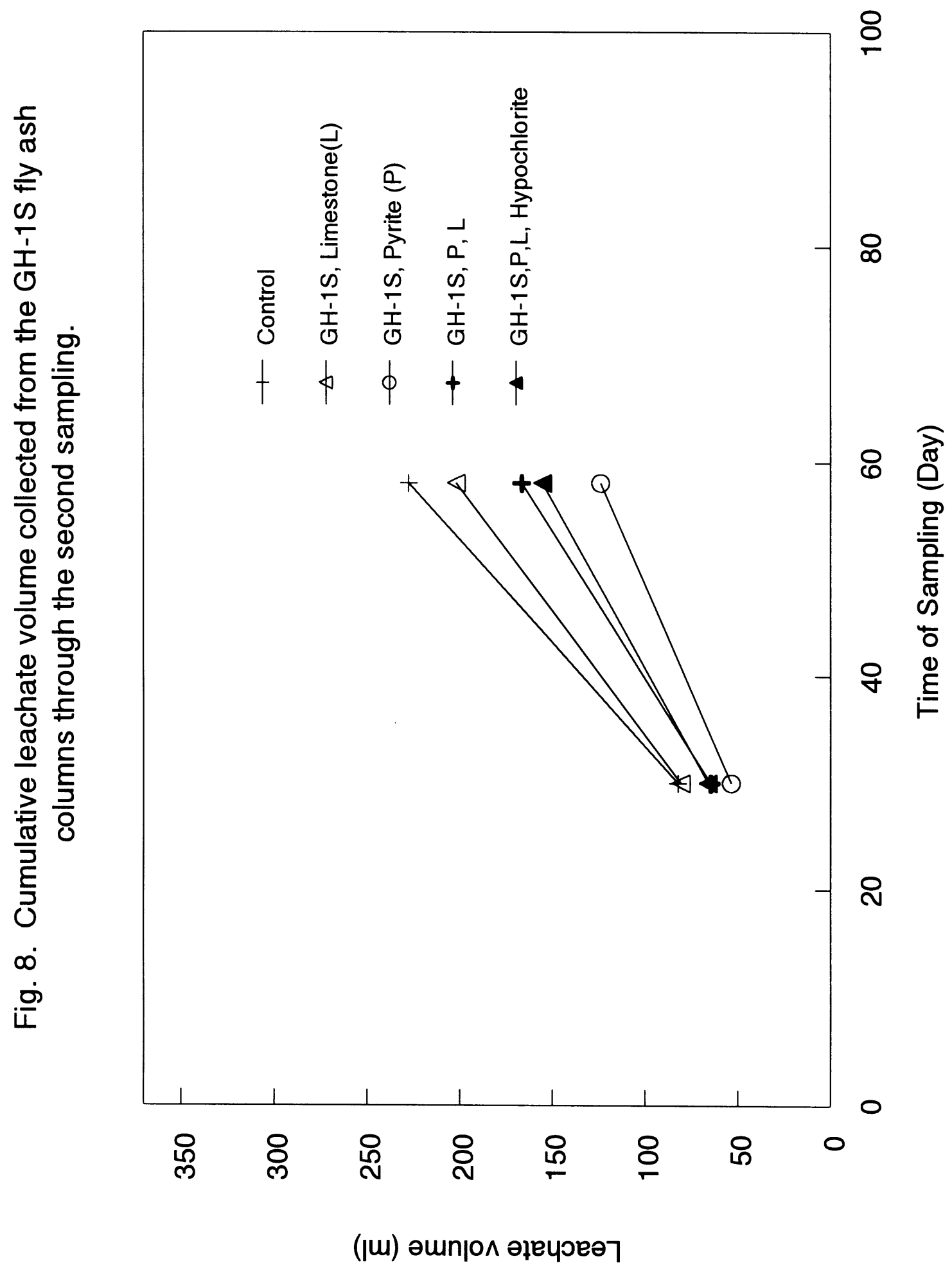




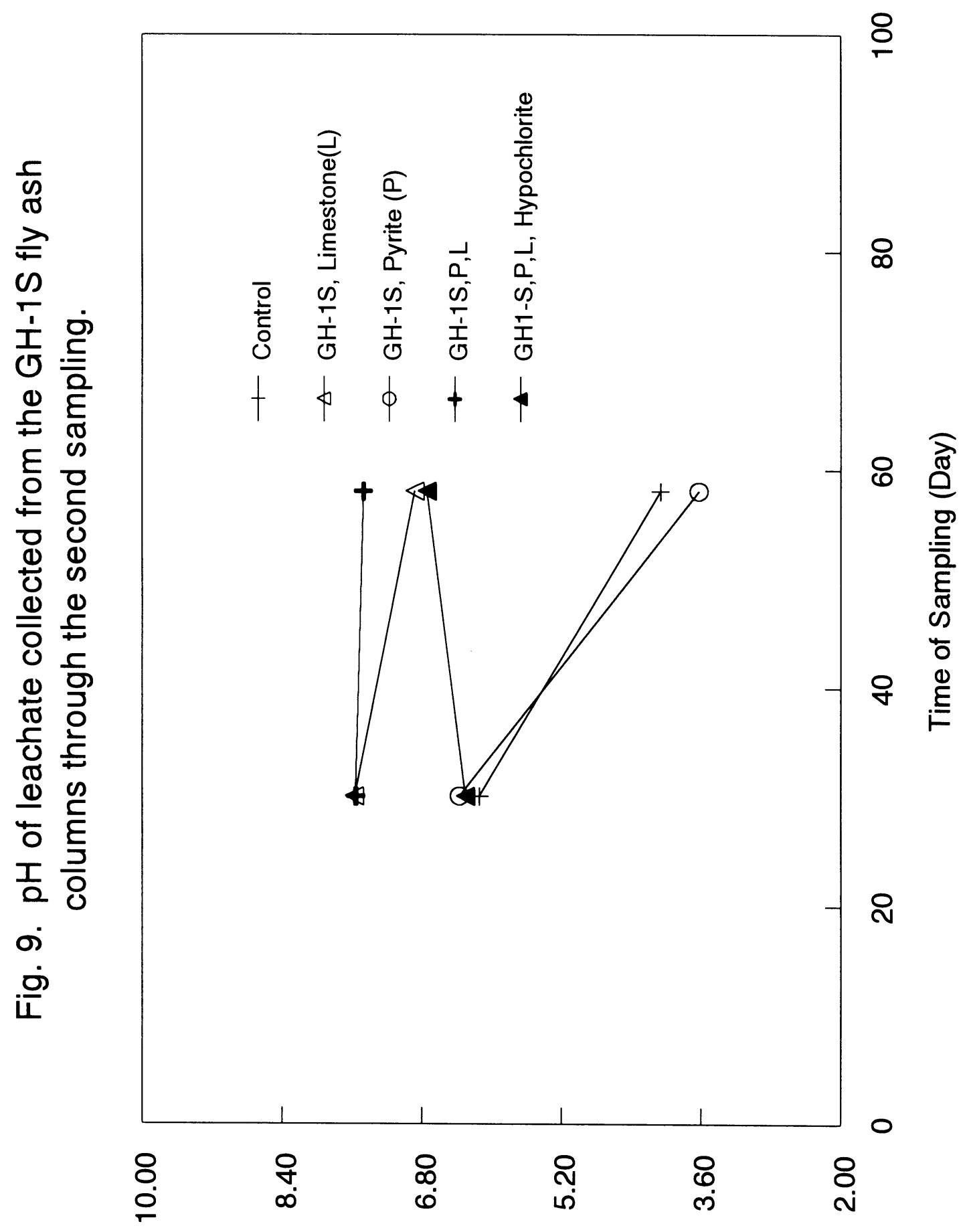




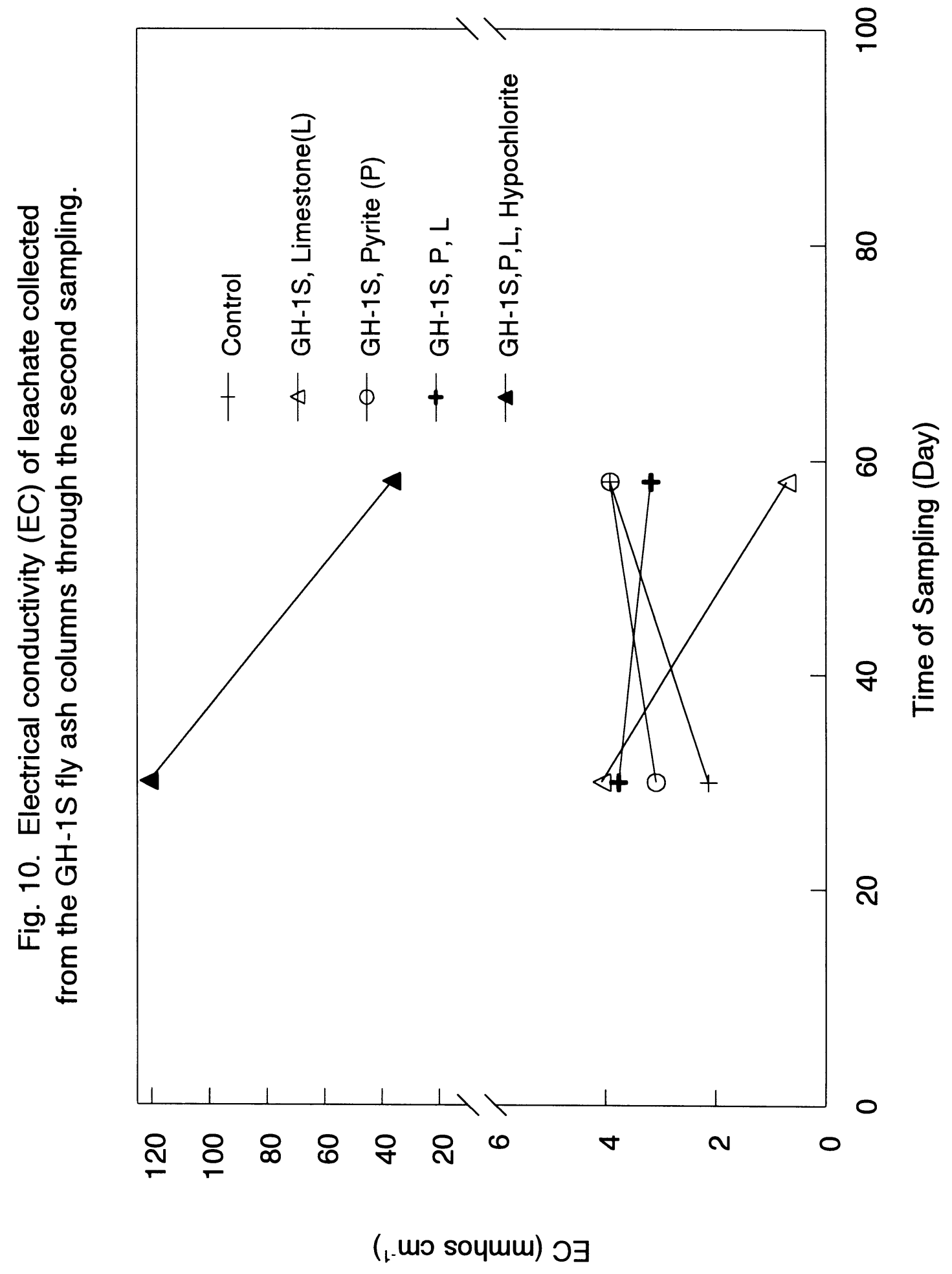




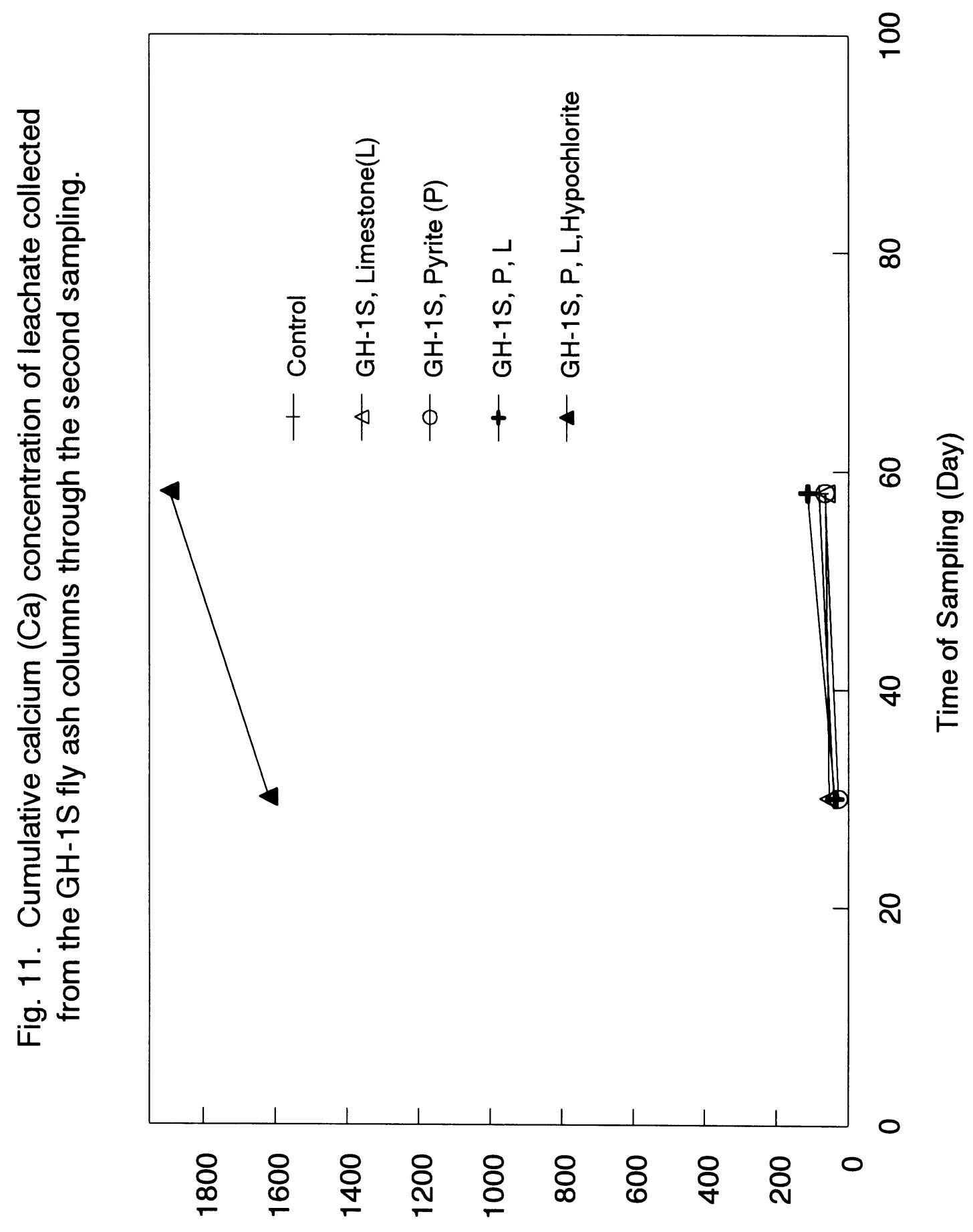

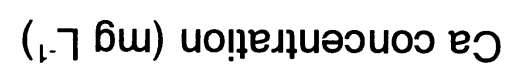




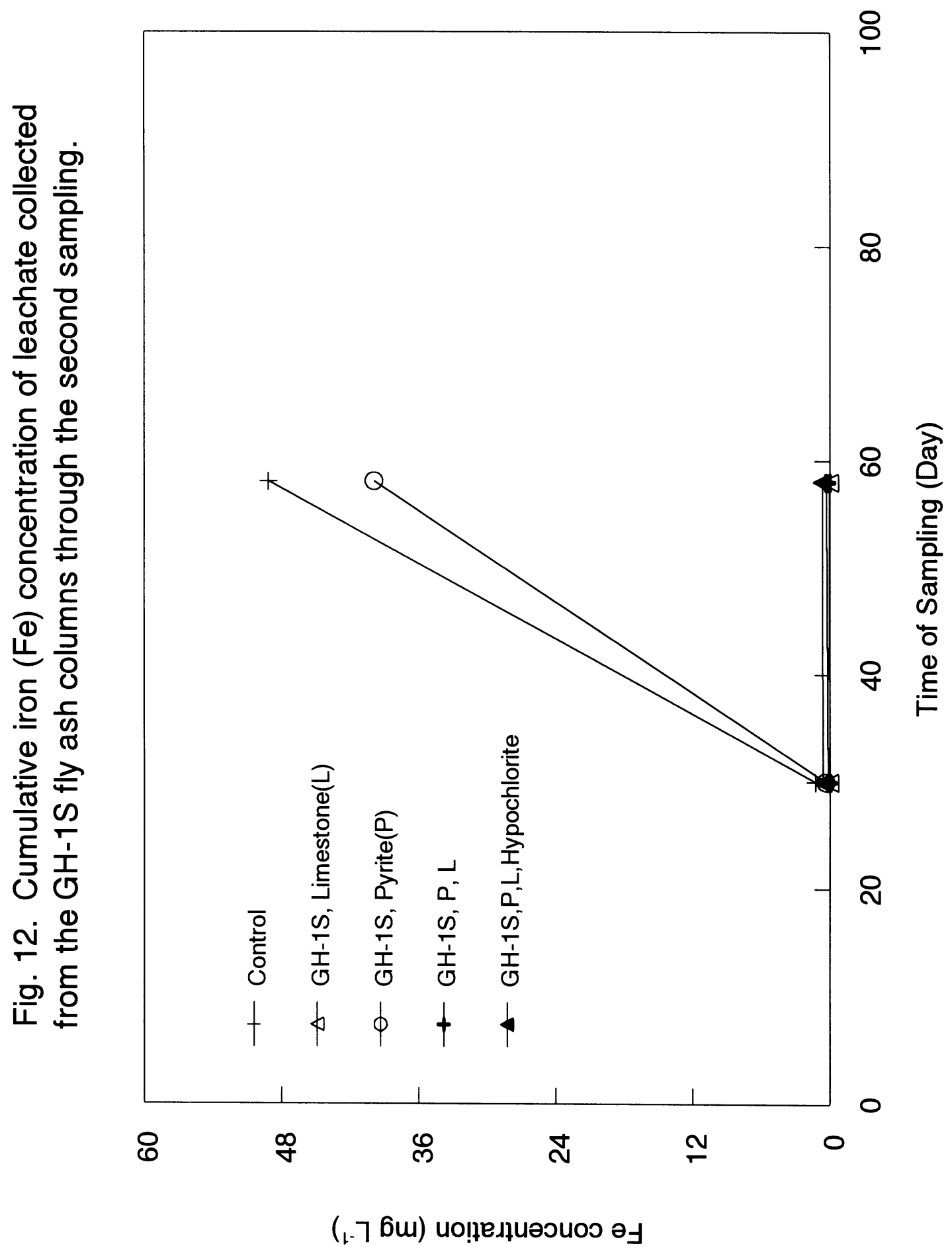




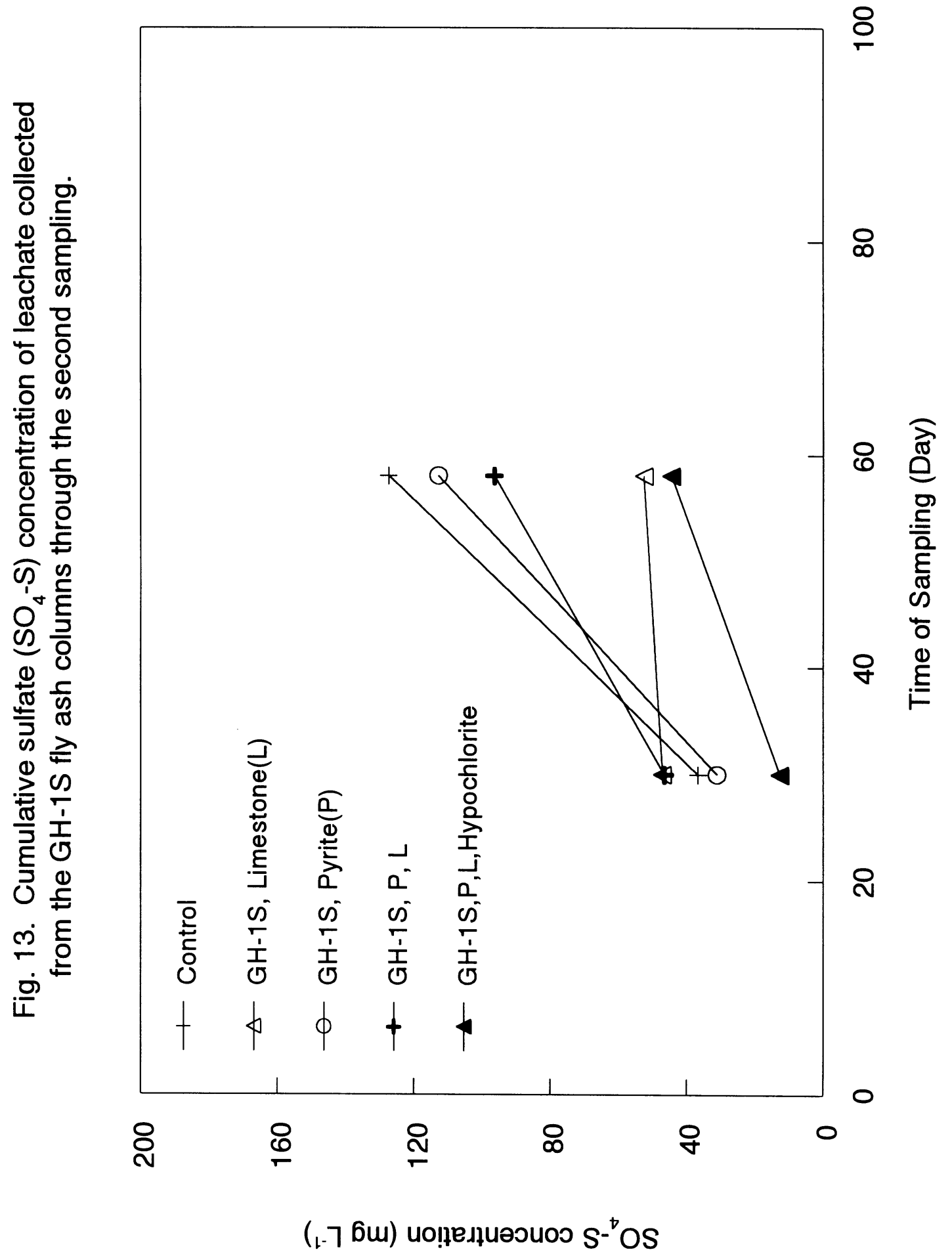




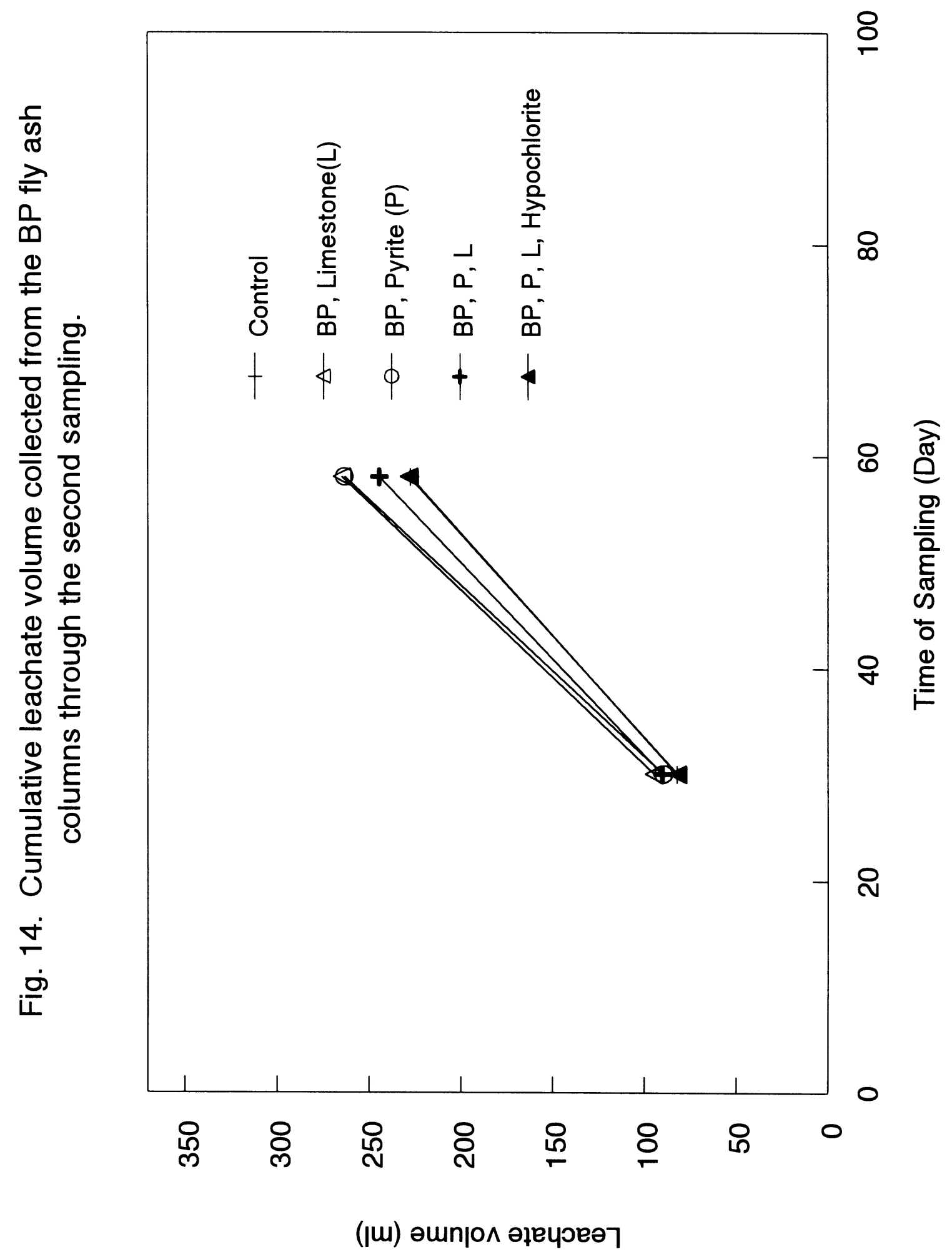




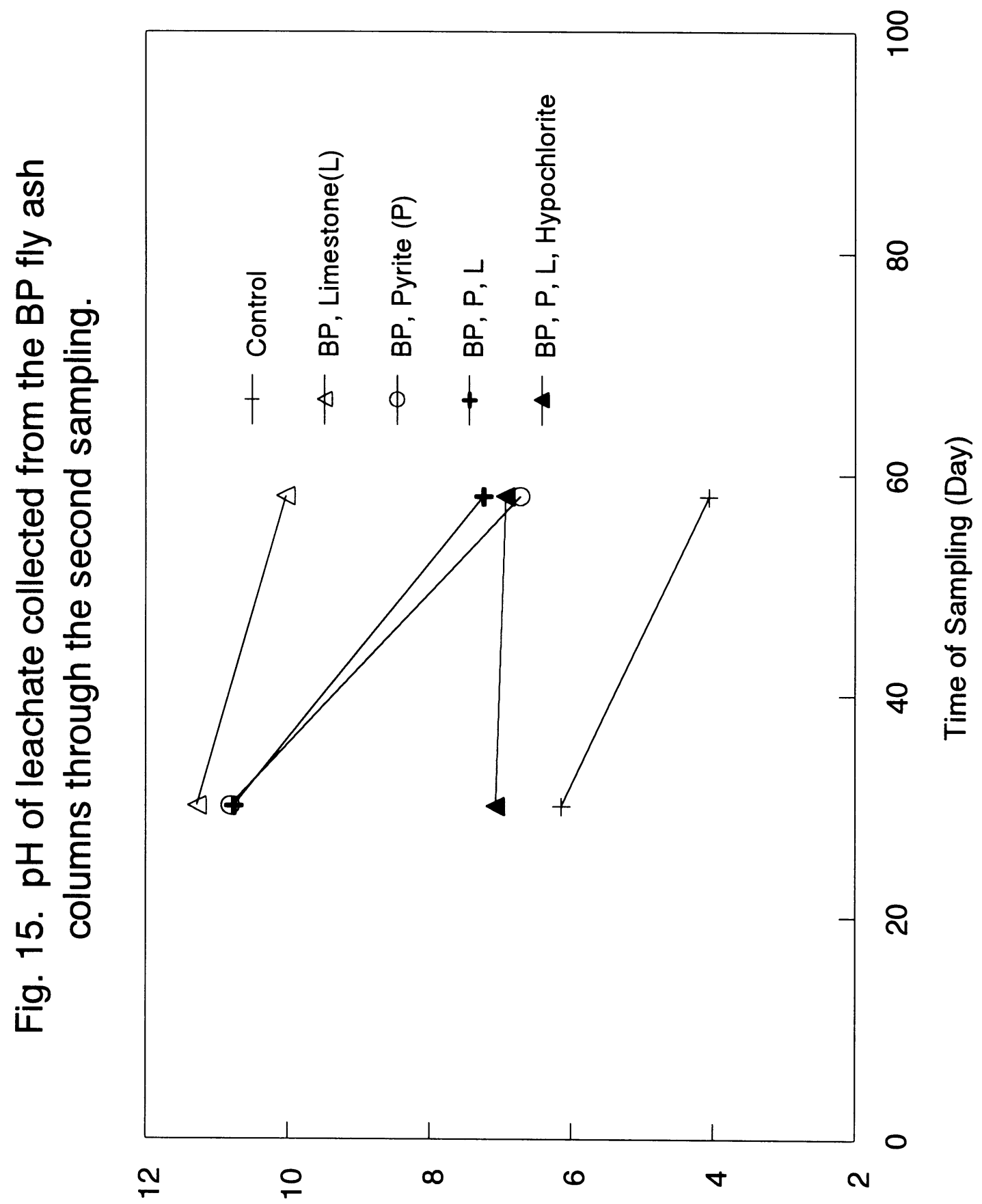

$H^{d}$ 


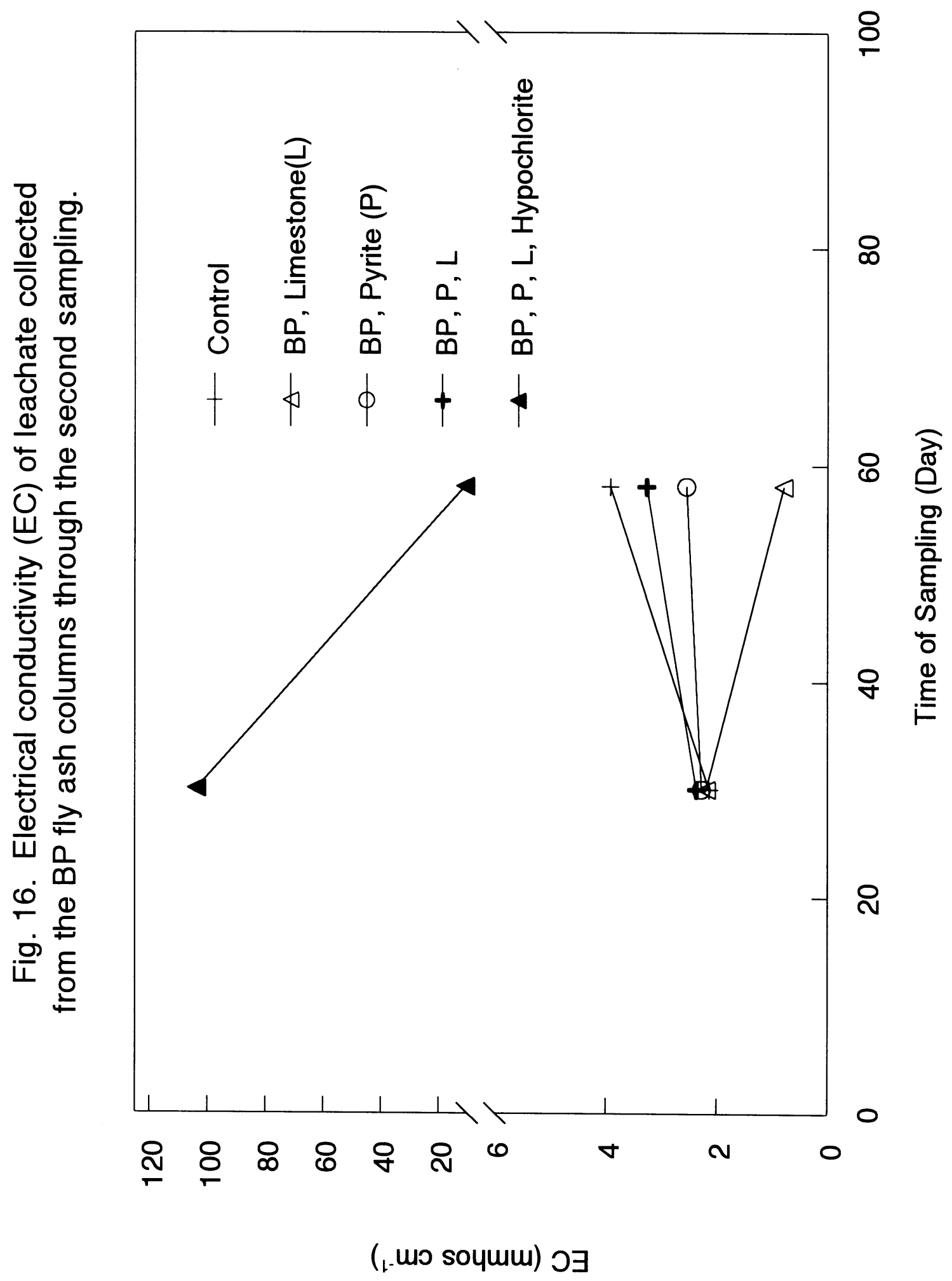




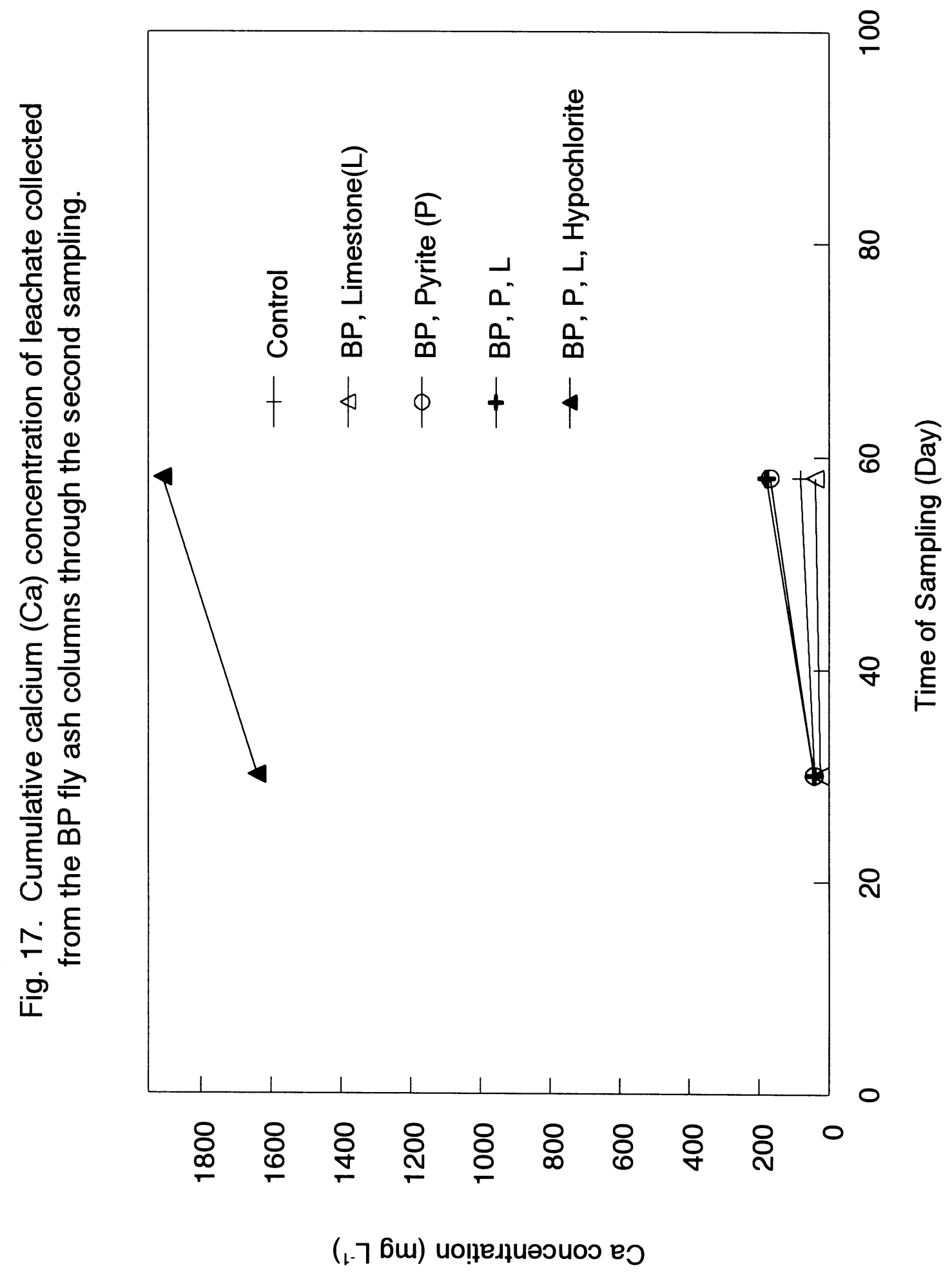




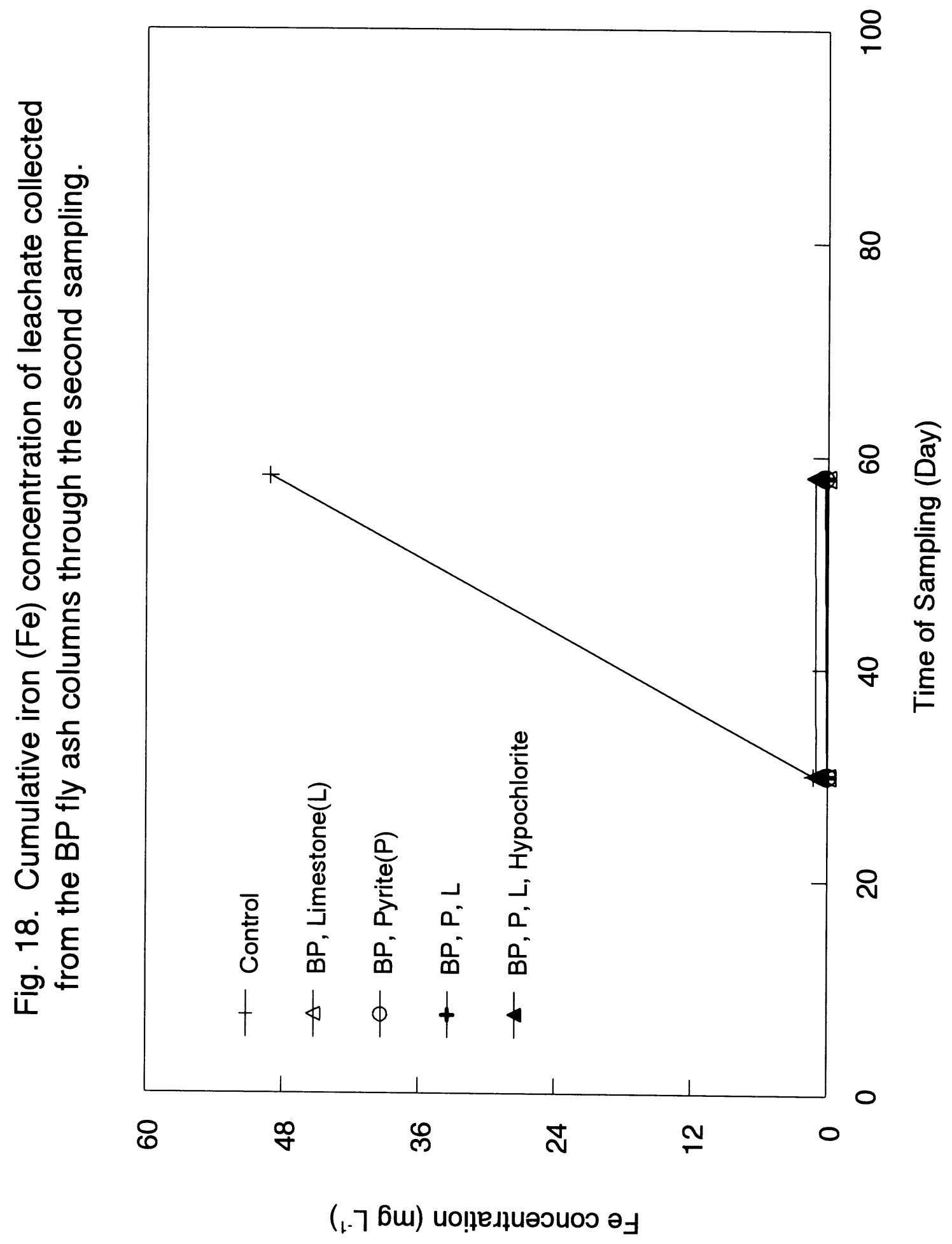




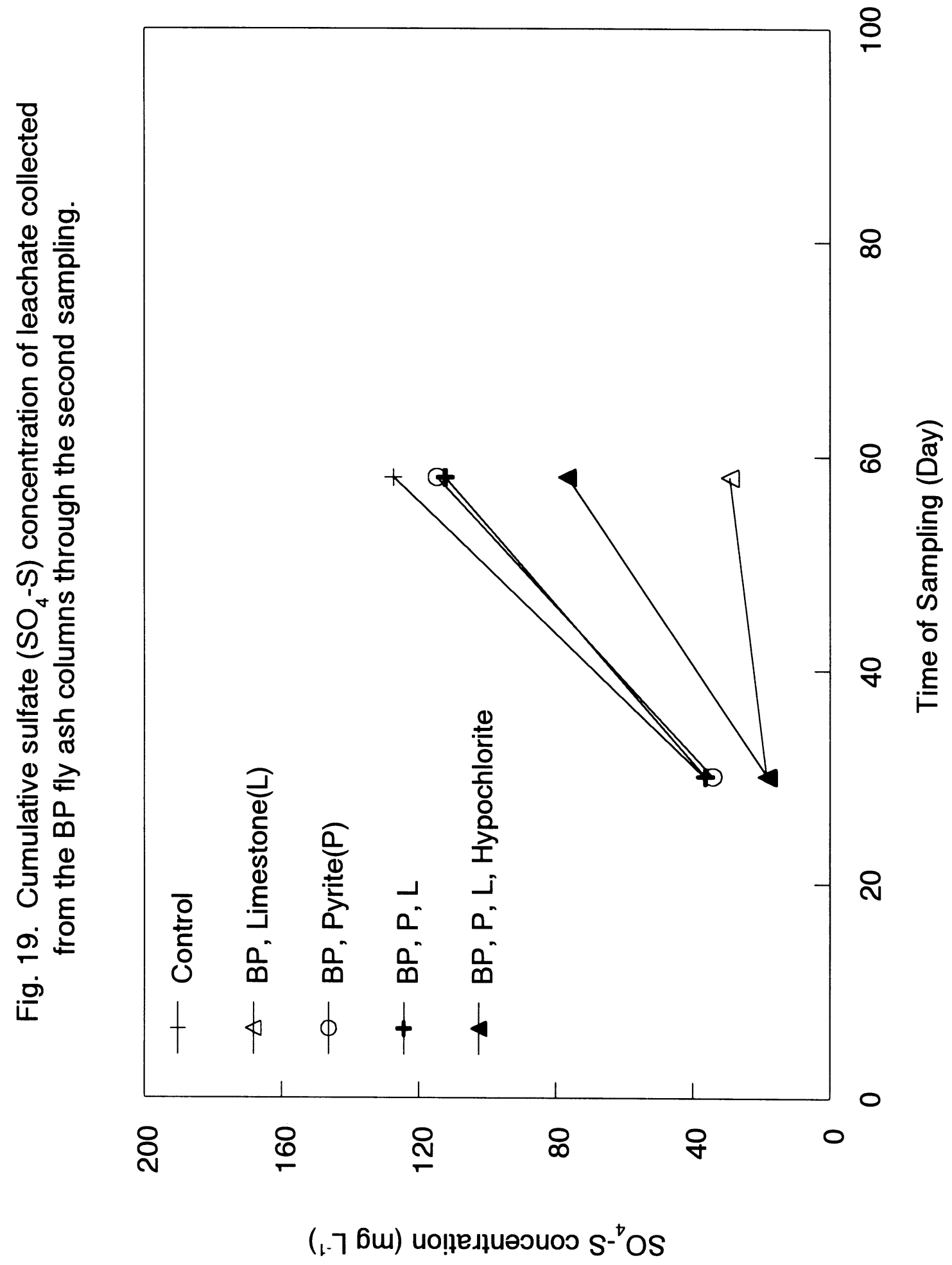


have dropped from about 6.2 to approximately 4.0. The leachate $\mathrm{pH}$ of these columns has dropped due to pyrite oxidation. All other treatments have maintained a circum - neutral $\mathrm{pH}$ to date (Fig. 9). As with the GH2 column set, the EC of the leachate collected from the fly ash + pyrite + limestone + hypochlorite treatments were extremely high due to the flushing out of the $\mathrm{Ca}$ (Figs. 10 and 11). The amount of $\mathrm{Fe}$ and $\mathrm{SO}_{4}-\mathrm{S}$ released into the leachate from the control and the fly ash + pyrite columns increased significantly from the first to second sampling (Fig. 12 and 13). This increase in $\mathrm{Fe}$ and $\mathrm{SO}_{4}$-S concentration in the leachates from the control and fly ash + pyrite columns is due to pyrite oxidation. The release of $\mathrm{Fe}$ from all other treatments was negligible. However, $\mathrm{SO}_{4}-\mathrm{S}$ concentration in the leachate from the fly ash + pyrite + limestone treatment also showed a significant increase. This increase has, as yet, not been accompanied with a drop in $\mathrm{pH}$ and increase in $\mathrm{Fe}$ release. To date the fly ash + limestone and fly ash + pyrite + limestone + hypochlorite columns have performed best with respect to $\mathrm{pH}$ and $\mathrm{Fe}$ and $\mathrm{SO}_{4}-\mathrm{S}$ released into their leachate.

\section{Leachate data from the BP fly ash column set}

Data on chemical composition and leachate volume are presented in figures 14 19. The $\mathrm{pH}$ of the leachates collected from the control columns have dropped from about 6.2 to approximately 4.0 due to pyrite oxidation. The fly ash + pyrite + limestone + hypochlorite column's leachate $\mathrm{pH}$ has remained steady at about 7 . The leachate from all other columns started at very high $\mathrm{pH}$ values of approximately 11.5 , but have now dropped to approximately $\mathrm{pH} 7$ (Fig. 14). Again, as with the other two fly ash types, the $\mathrm{EC}$ of the leachate from the fly ash + pyrite + limestone + hypochlorite columns was initially very high at 106 mmhos $\mathrm{cm}^{-1}$, but had dropped to $10.7 \mathrm{mmhos} \mathrm{cm}^{-1}$ by the second sampling. This high EC is due to flushing out of the Ca (Fig. 16 and 17). Only the control released high amounts of both $\mathrm{Fe}$ and $\mathrm{SO}_{4}-\mathrm{S}$ into the leachate (Fig. 18 and 19). The leachate collected from the fly ash + limestone columns had a relatively small increase in the concentration of $\mathrm{SO}_{4}-\mathrm{S}$ (from 42 to $168 \mathrm{ppm}$ ). All other columns showed a significant increase in the amount of $\mathrm{SO}_{4}-\mathrm{S}$ released (Fig. 19) To date the fly ash + limestone columns have performed best with respect to $\mathrm{pH}$, and the amount of $\mathrm{Fe}$ and $\mathrm{SO}_{4}-\mathrm{S}$ released into their leachate.

\section{CITATIONS}

Zhang, Y.L. and V.P. Evangelou. 1996. Influence of iron oxide forming conditions on pyrite oxidation. Soil Sci. 161:852-864.

Zhang Y.L. and V.P. Evangelou. 1998. Formation of ferric hydroxide-silica coatings on pyrite and its oxidation behavior. Soil Sci. 163:53-62.

Vandiviere, M.M. and V.P. Evangelou. 1998. Comparative testing between conventional and microencapsulation approaches in controlling pyrite oxidation. J. Exploration Geology. In Press. 